\title{
Investigação sobre a transversalidade social, disciplinar e geográfica de um modelo de ensino-aprendizagem da história através de fontes objetuais e criação de museus de aula ${ }^{1}$.
}

\author{
Research about social, curricular and geographical transversality of a \\ teaching and learning history model based on ojbects as primary \\ sources and classroom museums.
}

Glória Solé ${ }^{2}$

Nayra Llonch ${ }^{3}$

\section{RESUMO}

O artigo parte da problemática da percepção e compreensão histórica, indispensável para construir uma cidadania crítica, dos cidadãos do futuro (o aluno da educação primária), assim como dos futuros professores que vão ensinar os alunos no futuro (estudantes de licenciatura de educação primária). Apresenta-se dois modelos de ensino-aprendizagem de história implementados nos dois estudos de caso adaptados a idades e contextos geográficos distintos (caso 1: estudantes de magistério de uma universidade espanhola e no caso 2 alunos de educação primária portugueses). Apresenta-se os resultados dos modelos em ambos os contextos e destaca-se a transversalidade social, disciplinar e geográfica do modelo de ensino-aprendizagem proposto.

Palavras-chave: Educação Histórica. Modelo. Ensino através dos objetos. Museu de sala de aula. Transversalidade.

\footnotetext{
1 Este trabalho é financiado pelo Centro de Investigação CIEd- de Educação, Instituto de Educação, UMinho, através de fundos nacionais, de FCT / MCTES-PT.

2 Professora Auxiliar da Universidade do Minho, no Departamento de Estudos Integrados de Literacia, Didática e Supervisão (DEILDS) do Instituto de Educação, Universidade do Minho (UMinho, Portugal).Investigadora do Centro de Investigação em Educação (CIEd), Universidade do Minho.

3 Profesora lectora, Departamento de Didácticas Específicas, Facultad de Educación, Psicología y Trabajo Social, Universitat de Lleida, Espanha. Investigadora do Grupo de investigação consolidado DHiGeCs (Didáctica de la História, la Geografía y otras ciencias sociales) de la Universitat de Barcelona. Forma parte de la Red 14. Red de Excelencia de Investigación en Enseñanza de las Ciencias Sociales.
} 


\section{ABSTRACT}

The article's starting point is the problem of perception and understanding of history -which is essential to create a critical citizenship- by future citizens (primary school students) as well as future educators (teachers training university students). The article proposes two models of teaching and learning history and its development in two case studies adapted to different age s and geographical contexts (case 1: teachers training degree students of a Spanish universityand case 2: Portuguese primary education pupils). Results of the development of the teaching and learning model in both contexts are presented at the same time that the social, curricular and geographical transversality of the model proposed is exposed.

Keyword: History Education. Model. Teaching through objects. Classroom museum, transversality.

\section{Introdução}

Este artigo procura demonstrar a relevância e as potencialidades da didática do objeto e da construção do museu de sala de aula para a compreensão histórica e temporal dos alunos independentemente do nível de escolaridade (desde o primário a univeristário), com base em dois estudos empíricos que aqui se descrevem no âmbito da Educação Histórica. Ao mesmo tempo, destaca a pertinência de trabalhar com objetos do passado e com elementos do património familiar para consciencializar os alunos de educação básica e seus futuros professores da relevância do legado histórico, do respeito aos vestígios do passado como elementos significativos da nossa própria história e identidade e a conceção de uma identidade familiar e social através dos objetos e outras fontes (orais, gráficas, etc.).

No referencial teórico apresentam-se e analisam-se vários estudos internacionais que procuram evidenciar a importância da utilização de objetos em sala de aula como fontes históricas, assim como a construção de museus, para o desenvolvimento de competências ao nível da compreensão histórica desde os primeiros anos de escolaridade.

Apresentam-se ainda dois modelos que estiveram na base da implementação dos dois estudos de caso que aqui se descrevem, nomeadamante sobre a "A didática do objeto e ferramentas de análise das fontes objetuais" e "Museus de aula e suas potencialidades didáticas", que visam apresentar o potencial didático dos objetos para o ensino da história, como fontes primárias potenciadoras do acesso ao passado pelos vestígios materiais construídos pelo ser humano e que permite conhecer outras facetas da vida do ser humano, as vivências do quotidiano. Pela especificidade desta fonte histórica, o ser material (física) e táctil (sensorial) apresenta um conjunto de características que devem ser exploradas pelos 
alunos. O primeiro modelo relacionado com a didática do objeto sistematiza orientações de caracter pedagógico de como explorar objetos, que evidenciam a especificidade muito própria deste tipo de fonte histórica. O segundo modelo, que se articula obviamente com o primeiro, visa sistematizar também o carácter pedagógico da construção de museus de sala de aula, enunciando várias etapas que o professor deverá realizar com os seus alunos e elencar as competências históricas e transversais que este tipo de atividade/experiência pode proporcionar.

Na segunda parte deste artigo apresentam-se os dois estudos de caso, o primeiro realizado com futuros professores de Primária: "A construção de um museu com os objetos da familia: uma experiência de didática do objeto com futuros professores de primária”, o segundo com alunos de primária: "A construção do museu na sala de aula com objetos da família: um projeto com alunos do $2 .^{\circ}$ ano de primária", integrado no doutoramento da primeira autora do artigo.

O primeiro estudo de caso, está inspirado em estudos e teoria sobre a didática do objeto na sala de aula (DURBIN; MORRIS; WILKINSON, 1996; FERNANDES, 2009; PINTO, 2011; RIBEIRO, 2002; SANTACANA; LLONCH, 2012), por um lado, que consistiu na criação de um museu de aula, e por outro, em concreto através de um modelo transdisciplinar de criação de uma exposição museística através de recursos digitais e de uso de telemóvel com códigos quick response (QR) (LLONCH; MARTÍN, 2016). O projeto foi realizado com alunos do curso de formação de professores em educação primária e tem como objetivo mostrar aos alunos formandos metodologias e estratégias de ensino-aprendizagem da história diferentes dos métodos tradicionais, aproximando-os do estudo de fontes primárias, em concreto das objetuais, o que implica e facilita conexões com a sua história familiar, leva-os a uma aprendizagem por descoberta de conceitos e processos históricos e dota-os de habilidades digitais relacionadas com as TIC e a tecnologia móvel.

O segundo estudo de caso, está inspirado em vários estudos internacionais (COOPER, 1995; DURBIN; MORRIS; WILKINSON, 1996; HAWKES, 1996; HARNETT, 2006; HOODLESS, 1996; NULTY, 1998) com recurso a objetos e à construção de museu em sala de aula, em que se procurou investigar os benefícios da construção de um museu de sala de aula e as suas potencialidades para o desenvolvimento do pensamento histórico nas crianças (SOLÉ, 2009). Para a sua implementação utilizou-se a técnica do fio da história (Storypath ou Storyline), de acordo com várias etapas os alunos vão-se envolvendo ativamante neste processo de construção do museu. Com este projeto procurou-se analisar que ideias prévias convocam os alunos e posteriormente que evidências constroem acerca do passado quando exploram objetos antigos. Os dados recolhidos, discutidos e analisados tendo por base a Grounded Theory evidenciaram que a construção de museu de sala de aula por crianças revelou-se uma estratégia potenciadora de uma aprendizagem ativa e dinâmia sobre o passa do e a história, contribuindo para desenvolver um conjunto de competências históricas para além de outras 
de caracter transversal. Em termos de implicações, é de destacar que este estudo empírico serviu como exemplo de operacionalização das metas de aprendizagem (REPÚBLICA PORTUGUESA, 2010) de História em Portugal, coordenado por Isabel Barca, do qual fizemos parte.

O estudo paralelo de ambos os caso, com semelhanças e diferenças, estas últimas resultantes de diferentes objetivos popostos e da aplicação dos modelos a tipologias de alunos diferentes, e desenvolvidos em dois contextos geográficos diferentes (Espanha e Portugal), mostra a utilidade e pertinência de ambos os modelos ("A didática do objeto e ferramentas de análise das fontes objetuais" e "Museus de aula e suas potencialidades didáticas") para trabalhar uma didática da história inovadora e significativa, distanciada de modelos clássicos e memorísticos, em qualquer nível educativo, em qualquer idade ou em qualquer procedência geográfica e cultural. Assim o modelo de criação de um museu ou espaço museístico com objetos familiares que aquí expomos, através da análise do objeto como fonte do passado, pode transcender as paredes das instituições da educação formal para desenvolver-se em espaços patrimoniais ou museísticos convidando a comunidade a criar exposições com os seus objetos familiares e culturais (SABATÉ; GORT, 2012).

\section{Enquadramento Teórico (Estudos centrados na didática do objeto)}

Desde os pedagogos da Escola Nova muito se tem escrito sobre o potencial pedagógico do uso de objetos não só para o ensino das ciências sociais e da história, como para o desenvolvimento global das crianças, como foi o caso paradigmático de Maria Montessori. A partir dos anos 90 tem-se assistido a um incremento de vários estudos que se centram no uso de fontes objetuais no ensino da história, demonstrando as suas potencialidades para o processo de construção do conhecimento histórico e da compreensão histórica em contexto de sala de aula. Muitos destes estudos basearam-se nas ideias expressas por Durbin, Morris e Wilkinson (1996) na obra conceituada A Teacher's Guide to Learning from Objects, onde os autores apresentam um conjunto de factores que justificam a utilização dos objetos na sala de aula, destacando as potencialidades da sua utilização para o desenvolvimento do pensamento e compreensão histórica. Sustentam que a análise e interpretação de objetos é bem diferente da exploração de outras fontes materiais. Só com os objetos se pode observar certos pormenores: ter a perceção do tamanho, do peso, da forma, a exatidão da cor; experimentar sensações de cheiro, tato, temperatura; contactar com objetos reais do passado e aceder assim às vivências de outras épocas. Durbin, Morris e Wilkinson (1996) sustentam que a utilização de fontes objetuais contribuem para uma aprendizagem ativa, de acesso a informação que 
não está escrita, valorizando-se os objetos que nos rodeiam, promovendo experiências sensoriais, tácteis e a três dimensões, contribuindo para estimular a moti vação, a curiosidade, a pesquisa e a vontade de saber. A sua utilização reforça competências transversais ao nível da comunicação, ao proporcionar o desenvolvimento de competências linguísticas, através de exercícios de descrição em que se utilizam verbos, adjectivos, vocabulário diversificado ao nível da forma (como é?), material(de que é feito?) e sua função (para que serve?), bem como o questionamento (o interrogar as fontes) e o colocar hipóteses, estimulando a discussão e a oralidade. Também a investigadora Cooper $(1995,2005)$ destaca que é importante que as crianças aprendam a observar os objetos, a ter prazer nisso e a aprender a fazer perguntas do género: "O que é?; De que é feito? Porquê? Que idade tem? Como é usado? Que impacto teve na vida de quem o usou?" (COOPER, 2005, p. 22).

Na linha de investigação anglo-saxónica vários estudos têm demonstrado que a utilização de fontes objetuais por alunos ajudam a desenvolver a compreensão histórica e a aquisição de conceitos históricos e o desenvolvimento de conceitos substantivos associados ao tempo histórico como: cronologia, mudança, continuidade e progresso, assim como o de evidência e empatia hitórica (HAWKES, 1996; HOODLESS, 1996; HARNETT, 2006; NULTY, 1998). Alguns destes estudos com recurso exclusivo ou não à utilização e exploração de objetos para analisar a compreensão histórica e temporal dos alunos, destacam a relevância da sua utilização em sala de aula para uma aprendizagem ativa da história.

Hawkes (1996) comprovou no estudo que realizou com crianças de 5 e 6 anos diferenças entre as que exploraram objetos em relação ao grupo de controlo que exploraram imagens. Constatou que a exploração dos objetos, proporcionou experiências sensorais e ajudou-as a desenvolver a noção de período e de cronologia (mais antigo, mais recente, da mesma época). Comparativamente à exploração das imagens, o contacto com os objetos revelou-se uma estratégia mais motivadora e facilitadora da compreensão histórica, promotora de uma maior autonomia nas tarefas e proporcionou um maior interesse nos alunos.

Hoodless (1996) relata algumas experiências realizadas com objetos com crianças de 6 anos, constantando que quando exploraram alguns dos objetos, como por exemplo uma botija de água para aquecimento, através do questionamento, descreveram o objeto (o que é? de que é feito?) aplicaram conhecimentos contextualizados que já possuíam de tempo sobre o passado em relação ao objeto observado. Tal como Hawkes (1996) também Hoodless (1996) considera que através do manuseamento e discussão sobre objetos do mesmo período se pode promover a conceção de tempo cronológico, e expandir o conceito de época, embora esta afirmação seja questionável tratando-se de crianças tão pequenas que ainda não dominam o conceito de duração. Segundo a autora, contribuiu esta experiência para reconhecerem semelhanças e diferenças, ao comparar objetos com a mesma função de épocas diferentes, constatando mudanças e permanências. Com crianças mais velhos as fontes objetuais podem ser utilizadas de uma forma mais aprofundada, exploradas como fontes de investigação 
histórica, aplicando os procedimentos investigativos dos historiadores, realizando deduções, inferências a partir do questionamento e do cruzamento de informações.

Também a linguagem pode ser estimulada através do pensamento e resolução de problemas, estando esta associada intrinsecamente ao estudo da história, como o demosntra o estudo de Nulty (1998) realizado com crianças do $1 .^{\circ}$ e $2 .^{\circ}$ ano (6-8 anos), tendo utilizado objetos relacionados com uma unidade de estudo sobre pessoas famosas (Cleópatra, Mary Seacole, Pocahontas e Isabel I), para estimular a resolução de problemas. Comprovou que o grupo que usaram objetos desenvolveram mais ideias sobre o que fazer, mais hipóteses para testar, observaram melhor os acontecimentos, propuseram mais explicações e foram capazes de delinear melhor a tarefa.

Multiplicam-se estudos similares por outros países da Europa. Em Malta, Vella (2001) realizou um estudo qualitativo com crianças do ensino primário (5, 7 e 10 anos) que trabalharam em várias sessões (pré-intervenção, intervenção e pós-intervenção) com diversas fontes históricas: artefactos, imagens e textos escritos. Contatou ao nível da competência lingüística diferenças entre os mais velhos e os mais novos, como seria de esperar, os mais velhos (de 10 anos) expressaram-se de forma mais articulada e melhor, com linguagem mais complexa nas descrições dos objetos, mas os mais novos ( 5 anos) foram mais imaginativos. Relativamente à dimensão temporal foi notória a utilização de vocabulário de tempo quando descreviam os objetos (ex. em relação ao ferro de passar) surgindo expressões como "é antigo", "velho", "é rústico", mas sem o datarem concretamente.

Em Portugal foram realizados vários estudos com recurso a objetos como estratégia de ensino em sala de aula (RIBEIRO, 2002; FERNANDES, 2009) e em contexto de museu (PINTO, 2011). Ribeiro (2002) realizou um estudo descritivo com alunos do 5. ${ }^{\circ}$ ano (10-11 anos), em contexto de sala de aula, em que utilizou objetos arqueológicos do período Pré-histórico e Romano, com o objetivo de analisar a progressão do pensamento arqueológico dos alunos. Constatou que os alunos revelaram maior dificuldade em realizarem inferências a partir dos objetos arqueológicos Pré-históricos do que romanos, justificada pela incapacidade de identificação e reconhecimento da função destes objetos estranhos às suas vivências. Destacase ainda o estudo de Aguiar (2015) que procurou analisar como os kits de objetos manuseáveis que o Museu da Maia leva às escolas no âmbito do projeto, o "Ver, Tocar e Sentir a Maia" promovido pelo Museu de História e Etnologia da Terra da Maia - são recursos e estratégias cruciais de mediação patrimonial em museus, criando espaços para experiências pessoais e educacionais produtivas que promovem uma aprendizagem efetiva, ativando memórias singulares também em contexto escolar.

Em Espanha destacamos o estudo, um pouco similar ao anterior, realizado por Egea e Arias (2015) num âmbito do "proyecto de innovación docente IES Arqueológico" que consistiu em implementar uma série de propostas com recurso à didática do objeto e metodologia aqueológica para o ensino da história. Procuram com este projeto responder à seguinte 
questão: "Como se pode introducir o património material e arqueológico nas aulas de uma maneira ativa e significativa?" Para além de simulações de escavações arqueológicas, levaram às escolas fontes arqueológicas, permitindo que o museu se abra às escolas.

No Brasil, destaca-se o projeto coordenado por Schmidt e Garcia (2007) Recriando Histórias, que envolveu toda a comunidade escolar e a comunidade mais ampla, procurando através da recolha de documentos e objetos de acervos familiares, promover a construção de conhecimento histórico. Ainda no Brasil, o estudo Cainelli (2006) realizado no âmbito do projeto Educação Histórica: iniciando crianças na arte do conhecimento histórico, implementado com alunos de 8 anos, procurou refletir sobre as perspetivas do ensino de História com crianças, atendendo à utilização de objetos antigos e a sua relação com objetos do presente, para a construção de narrativas e o desenvolvimento de noções temporais. Conclui a autora que as crianças partem das suas referências familiares, das suas observações e inferências para a construção e o desenvolvimento de noções de historicidade e de compreensão temporal, contrapondo o passado ao presente.

Esta breve revisão de literatura que aqui apresentamos, sobre a utilização de objetos em sala de aula para o ensino de ciências sociais e história permite, evidenciar a investigação que se tem desenvolvido em vários países, comprovando-se que a utilização de fontes objetuais contribuem para promover competências históricas e transversais.

\section{Modelos}

\section{Didática do objeto e ferramentas de análise das fontes objetuais}

Para ambos os estudos de caso procurou-se trabalhar o conceito de fonte histórica e o conceito de fonte objetual. Para tal baseamo-nos nos argumentos de Durbin, Morris e Wilkinson (1996) e Santacana e Llonch (2012) que sutentam a potencialidade das fontes objectuais para o desenvolvimento do pensamento e compreensão histórica.

Os "argumentos didáticos a favor do ensino com objetos" de Santacana e Llonch (2012, p. 27-30) são os seguintes:

1. A sua materialidade, que serve para fixar a imagen do conceito;

2. Facto de atuar como elementos de referencia; 
3. A capacidade de atuar como um íman que atraí a atenção do aluno;

4. Permitem ensinar mediante o uso do método hipotético-dedutivo;

5. Permitem trabalhar o método indutivo;

6. São um suporte para a imaginação;

7. Podem provocar situações empáticas;

8. São inclusores da mente;

9. Atuam como suportes da memória;

10. São elementos reais que se opõem ao mundo virtual em expansão;

Com base nestes argumentos, Santacana e Llonch (2012, p. 53-62) propõem um modelo de análise das fontes objetuais do passado (MAFOP) assente em oito grandes eixos:

1. identificação do objeto

2. análise morfológica

3. análise funcional

4. análise técnica

5. análise económica

6. análise sociológica

7. análise estética ou artística

8. análise histórico/cultural.

O interesse didático deste modelo de análise vai mais além da aprendizagem da história, visto que, para além dos trabalhos transdisciplinares que se podem realizar a partir da análise de um objeto, o processo de elaboração da própria análise relaciona-se com quase todas as áreas curriculares dos diferentes currículos educativos de muitos países desde educação infantil a educação secundária, passando pela educação primária e pelo ensino universitário de formação de futuros professores. Assim, pois, em relação a um dos oito eixos, o da análise morfológica, como exemplo, implica o desenvolvimento de capacidades mentais como observação e análise; seguida de competências linguísticas para realizar a descrição global e de cada uma das partes que o constituem; as competências da área visual e plástica desenvolvem-se quando desenham o objeto, fazer um esboço ou esquema de composição, 
geometrizá-lo ou fotografá-lo em diferentes ângulos e perspectivas, ou analisar as suas cores; a competência matemática desenvolve-se quando se mede o objeto; desenvolvem-se conceitos relacionados com a tecnologia quando se analisam os materiais de que é feito o objeto, etc.

Neste sentido, o modelo de análise, adequadamente adaptado a vários níveis educativos, converte-se numa poderosa ferramenta de didática da história, das ciências sociais e de outras áreas curriculares (NICOLESCU, 2009; MARGERY, 2010).

\section{Museus de aula e suas potencialidades didáticas}

Nem sempre os alunos têm oportunidade de visitar museus e a construção de um muse u de sala de aula tem-se revelado como uma ótima estratégia de ensino por proporcionar o envolvimento dos alunos de vários níveis de escolaridade no processo de aprendizagem de história, contribuindo para desenvolver o pensamento histórico como um todo. Vá rios projetos de experiências de construção de museus em sala de aula têm demonstrado o envolvimento das crianças nas várias etapas da sua concretização independentemente da temática escolhida, como os seguintes exemplos de projetos bem ilustram: Cooper (1995) subordinado ao tema Quando éramos bebés; Kerrigan (2001) descreve o projecto Museu Comunitário Escolar, Barnsdale-Paddock e Harnett (2002) subordinado ao tema "brinquedos" e Singer e Singer (2004a, 2004b) museus com objetos da família centrados em várias temáticas (Imigração, II Guerra Mundial), ou o projeto Recriando Histórias de Schmidt e Garcia (2007).

A construção de museus na sala de aula pode ser um valioso meio para envolver os alunos na comunicação e na organização de informação histórica. É uma atividade que permite promover um conjunto de competências históricas e transversais:

1. Desenvolver a comunicação (oral, escrita e digital);

2. Promover o questionamento das fontes objetuais históricas e o levantamento de hipóteses;

3. Adquirir e mobilizar vocabulário histórico;

4. Promover a compreensão do tempo histórico;

5. Desenvolver o conceito de cronologia ao nível da datação e sequencialização;

6. Desenvolver outros conceitos estruturais do ensino da história: evidência histórica, explicação histórica, empatia histórica, significância histórica, causalidade, mudança, comparação; 
7. Promover a aprendizagem cooperativa pela divisão das tarefas, da perseverança, da autonomia no trabalho e de um forte sentido de responsabilidade e respeito;

8. Proporcionar interesse sobre o passado a partir do familiar pelo contacto com os objetos, partindo do concreto para o abstrato;

9. Envolver familiares (pais, avós ou outros pessoas da família) e toda a comunidade educativa;

\section{Etapas na construção de um museu na sala de aula}

Para a construção de um museu da sala de aula é preciso atender a um conjunto de sugestões e recomendações tidas em consideração no projecto que realizamos no âmbito de doutoramento (SOLÉ, 2009, p. 633-644) com alunos portugueses do 2.0 ano de escolaridade, subordinado à temática "Museus dos objectos antigos da nossa família".

Modelo de criação de um museu de sala de aula (MCMSA):

$1{ }^{\circ}$ momento- criação do contexto do museu (que tipo de museu vão construir e qual a sua finalidade);

2. ${ }^{\circ}$ momento - criação do local do museu (escolha do espaço onde será constituído) ;

3. ${ }^{\circ}$ momento- criação das personagens do museu (definem os papéis e as funções que cada um terá no museu);

4. ${ }^{\circ}$ momento-construção do contexto (a quem se destina e os seus objetivos);

5. ${ }^{0}$ momento-preenchimento de ficha de caracterização do objecto e montagem da exposição;

6. ${ }^{\circ}$ momento- inauguração do museu.

Outras orientações e detalhes para a construção de museus na sala de aula podem ser encontrados na Historical Association's Occasional Paper 7 (1994) e em Solé (2012a, p. 20-22, 2012b, p. 320-321). 


\section{Estudos Empíricos}

Estudo de caso 1- A construção de um museu com os objetos da familia: uma experiência de didática do objeto com futuros professores de primária

\section{Metodologia}

Esta investigação foi realizada durante três anos lectivos (2013-2014, 2014-2015 e 20152016) com estudantes do $3 .^{\circ}$ ano da Licenciatura em Educação Primária da Faculdade de Educação, Psicologia e Trabalho (FEPTS) da Universidade de Lleida (Espanha) na disciplina obrigatória de 9 ECTS "Didáctica das Ciencias Sociais - História General da Europa". No ano de 2013-2014 implicou 163 alunos, no ano de 2014-2015 envolveu 164 alunos e no ano de 20152016 participaram 104 alunos; sendo um total de 431 alunos participantes.

A investigação qualitativa, baseia-se numa experiência didática do objeto e método indutivo, desenvolve-se ao longo de sete meses, embora a criação do museu se realiza nos últimos dois meses durante seis sessões.

\section{Objetivos}

Os objetivos do trabalho realizado com alunos universitários são diversos e abarcam diferentes tipos de competências tanto concetuais como procedimentais: a) mostrar aos futuros professores e professoras o potencial dos objetos como fontes do passado através do uso de ferramentas e modelos de análise das fontes objetuais; b) aproximar o aluno às fontes do património local e familiar com a intenção de conhecer melhor aspectos históricos e sociais do século XX; c) tomar consciência do meio social e cultural através dos vestígios ou fonte, sobretudo as objetuais e orais; d) apresentar uma didática da história através do método por descoberta; e) mostrar metodologias e ferramentas de classificação de fontes; f) fomentar experiências de trabalho e de aprendizagem cooperativa; g) fomentar competências de pesquisa de informação e seleção crítica da informação; h) fornecer ferramentas para a criação de recursos didático digitais com base no uso de telemóvel, em concreto, com recurso digital aos códigos QR; i) articular a didática da história com outras disciplinas e materiais partilhados ao longa da formação de modo inter e transdisciplinar com a finalidade de mostrar modelos híbridos na formação de professores com a finalidade que possam ser replicados no futuro como profissionais de docência (BONASTRA; JOVÉ; LLONCH, 2015). 
Técnicas e instrumentos de recolha de dados

Utilizaram-se diversos instrumentos de recolha de dados: observação participante; trabalhos dos alunos; grelhas com itens de avaliação; relato auto-biográfico-história de vida; questionários (anónimos), e comentários abertos (anónimos) e algumas entrevistas gravadas em vídeo (não anónimas e voluntárias).

\section{Procedimentos}

Etapa $1 .^{a}$ - Fase prévia: conceito de fonte histórica, didática do objeto, método indutivo e introdução ao MAFOP (meses 1 e 2). Durante uma primeira etapa prévia, trabalhou-se o conceito de fonte histórica e realçou-se o tratamento dos objetos como fontes (SANTACANA; LLONCH, 2012). Além disso, através deste tema introduziu-se a ideia do método indutivo (LLONCH, 2010). Apresentou-se aos alunos o MAFOP constituído por oito campos de análise já anteriormente referidos e realizou-se uma primeira análise de prova através de trabalho em grupo e colaborativo.

Etapa $2^{\mathrm{a}}$ - Escolha de um objeto da família e elaboração(meses 3 e 4). Nesta fase realizouse um trabalho individual de análise exaustiva e que consistiu em analisar um objeto segundo o MAFOP e procurar relações com conceitos históricos contemporáneos do objeto. Deveria ser um objeto antigo da familia. No curso do ano lectivo 2013-2014, o objeto da família devia ter alguma relação com alguma temática trabalhada nas disciplinas anteriores de História e Geografia. No curso do ano lectivo de 2014-2015 o objeto devia estar relacionado com alguns temas que tinham sido ponto de partida do trabalho inter e transdisciplinar: uma fonte audiovisual sobre as missões pedagógicas da II República Espanhola (VAL DEL OMAR, 1932) e uma experiência sobre um professor da República exilado após a Guerra Civil Espanhola (JOVÉ, 2015). No curso do ano lectivo de 2015-2016 a escolha do objeto foi totalmente livre. Assim, cada aluno escolheu um objeto de família, analisou-o e estabeleceu conexões com os conteúdos históricos e transdisciplinares que como o dito objeto se podia ensinar.

Etapa $3^{\mathrm{a}}$ - Primeira fase de preparação da exposição museística: eleição do tema, documentação, catalogação e criação de recursos digitais(mês 5 e 6). Uma vez avaliado pelos professores o trabalho de análise do objeto de família realizado por cada aluno e aluna: a) levam-se para a sala os objetos (todos os que são facilmente transportados) e também trazem a fotografia do objeto; b) cria-se uma "loja" com os objetos e um mural com as fotografias para poder ser observado pelos alunos; c) elaboram-se fichas de classificação de objetos para catalogá-los; d) elabora-se um mapa conceptual em conjunto para se realçar as principais temáticas que se podem tratar através dos objetos que os alunos analisaram; e) a partir do 
mapa conceptual e dos intereses dos alunos e das permissas prévias escolhe-se uma temática sobre a qual se irá realizar a exposição; f) fase de documentação sobre a temática a partir da pesquisa de mais fontes primárias (testemunhos, fontes gráficas, mais objetos, etc.) e também secundárias; g) catalogação das fontes e criação de uma base de dados; h) criação de recursos digitais em forma de código QR como base documental da exposição.

Etapa $4^{\mathrm{a}}$ - Fase de montagem expositiva através da aplicação do MCMSA (mês 7). 0 primeiro momento do MCMSA desenvolveu-se já na etapa 3. ${ }^{a}$. Em esta etapa desenvolvem-se os momentos ou fases que vão do 2 ao 6 do MCMSA.

\section{Resultados}

As etapas que estão diretamente relacionadas com a criação do museu com objetos da família através da didática do objeto na sala de aula universitária com futuros professores de Educação Primária são a $3^{\mathrm{a}}$ e a $4^{\mathrm{a}}$, e desenvolveram-se nos seguintes momentos do MCMSA:

No $1^{\circ}$ momento, consistiu na seleção da temática da expoisção por parte dos estudantes e em responder à seguinte pergunta: o que queremos mostrar e explicar a partir dos nossos objetos? No curso do ano letivo 2013-2014 os cinco temas de exposição escolhidos (para dois grupos muito numerosos fez-se duas exposições, para o terceiro fez-se só uma): "O papel da mulher entre os anos 20 e 30 do séc. XX; "A educação na Catalunha entre os anos 30 e 70 do séc. XX; "A Guerra Civil, entre a vida militar e a vida quotidiana"; "A vida quotidiana durante a primeira metade do séc. $\mathrm{XX}$, e "A vida no campo e a vida na cidade durante o período da Guerra Civil". No curso do ano letivo 2014-2015 realizaram-se três exposições, uma para cada grupo classe, e os temas escolhidos foram "Revivendo o passado construindo o futuro", "A escola franquista" e "As povoações das missões pedagógicas". Enquanto que no curso do ano letivo de 2015-2016 só houve um tema para os dois grupos: "Havia uma vez um objeto..." Cada grupo turma dividiu-se em subgrupo de trabalho colaborativo, do qual surgiu um subâmbito temático expositivo à volta de um objeto.

Em relação à escolha do tema: "O facto de termos podido escolher o tema fez com que o anlisassemos com mais interesse" (Alumno 1-A1).

Em relaçao ao tabalho coopera tivo: "O projeto em grupo foi muito enriquecedor porque cada um constribuía com o que melhor sabe [...] Aprendi com a autogestão e o trabalho em grupo". (A2) "É interesante trabalhar a assim a história porque são os alunos que escolhem um tema que os motiva e que gostam". (A3) - Imagem 1. 


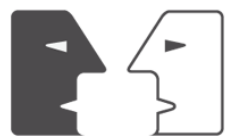

ANTIITESES

Imagem 1. Exposição de objetos e suas imagens para iniciar o trabalho emgrupo de escolha de uma temática museística.

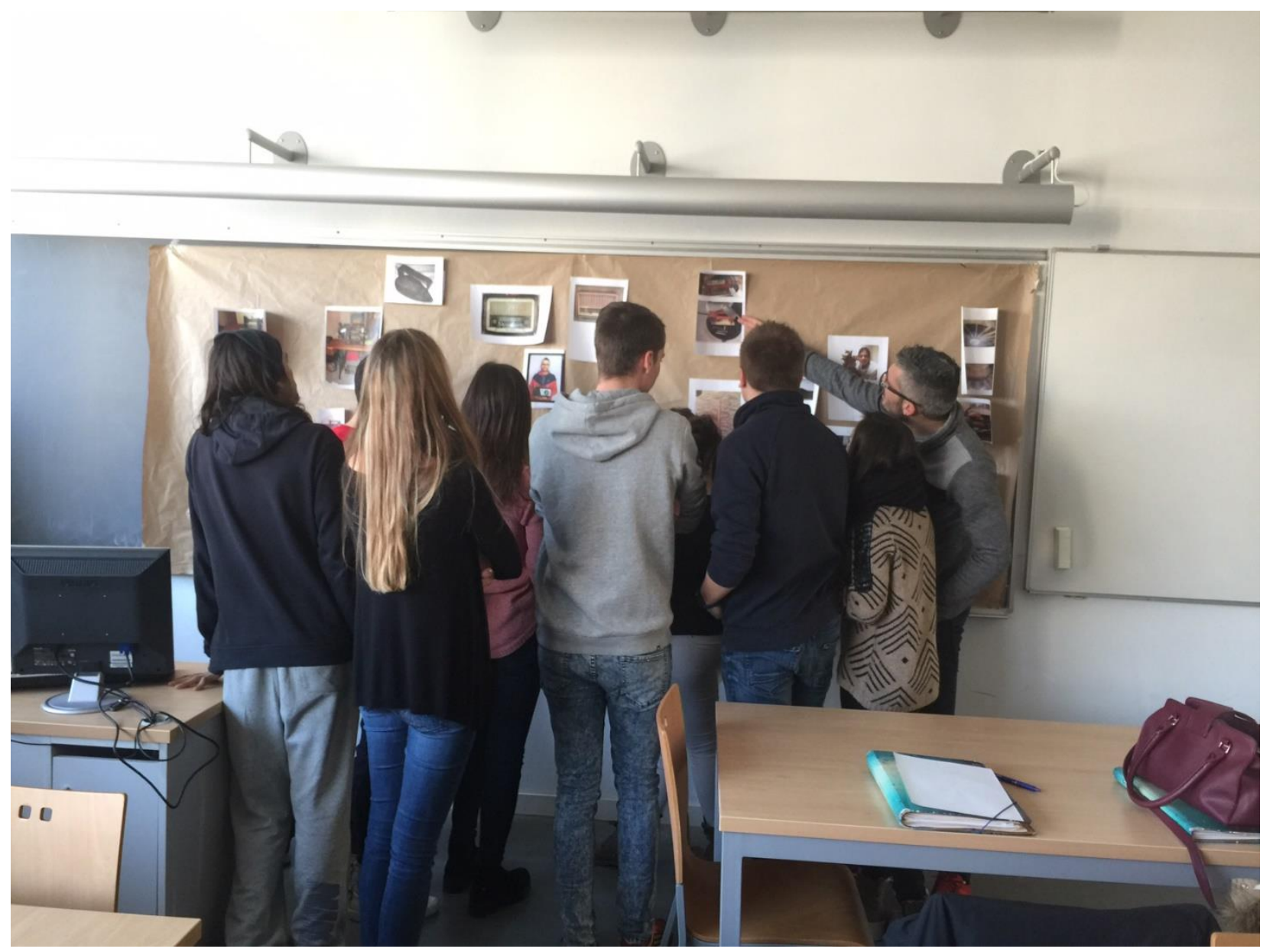

Fonte: autoras.

No $2 .^{\circ}$ momento, o espaço foi proposto pelos professores com a ideia de dar utilidade e sentido a espaços pouco utilizados da FEPTS. Os alunos visitaram-no, estudaram-no e analisaram para criar a sua proposta museística adaptada ao dito espaço. Nos cursos dos anos letivos 2013-2014 e 2015-2016 foi realizado un espaço exterior mais coberto e a duração foi efémera, para evitar estragos e furtos; enquanto que no curso do ano letivo 2014-2015 realizouse num espaço fechado e com a duração de um mês. - Imagem 2. 
Imagem 2. Espaço museístico no exterior de FEPTS com o título da exposição (curso 2015-2016).

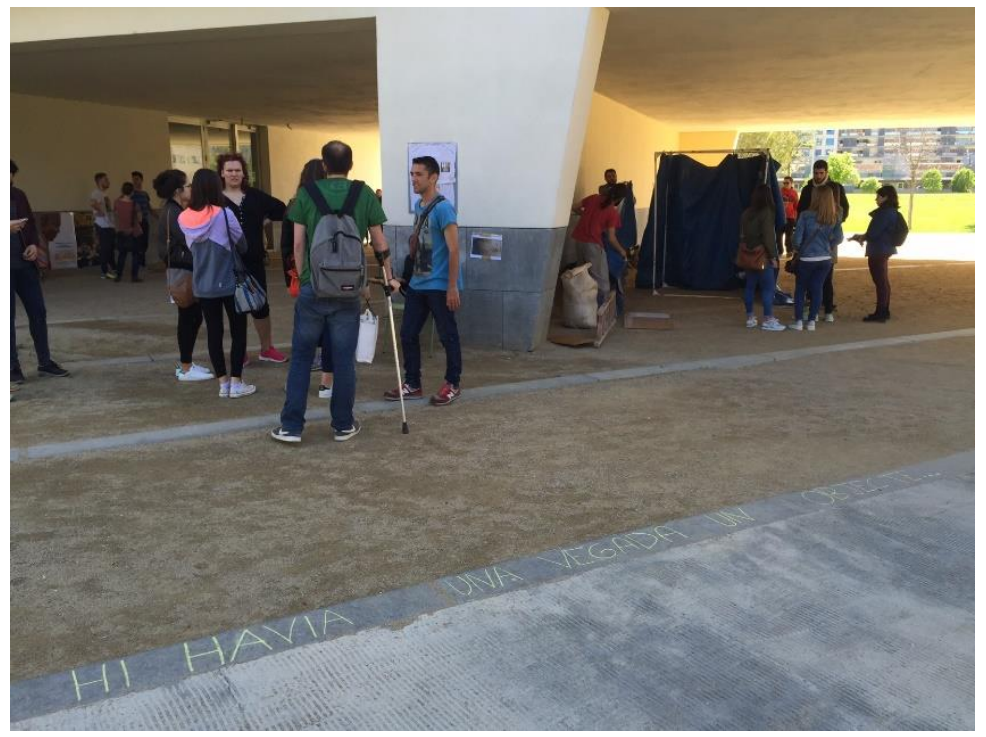

Fonte: autoras.

No 3. ${ }^{\circ}$ momento, no caso dos alunos universitarios omitiu-se, já que o trabalho de curadoria, criação de recursos digitais com material didático, desenho e criação de cartazes e outros elementos museísticos esteve a cargo de todos os membros de trabalho, sem distinção. "Realizar uma exposição é muito interessante mas ao mesmo tempo dá muito trabalho, mas fazendo-o em equipa gostamos". (A5)

No $4 .^{\circ}$ momento, os alunos consensualizam nos seus grupos de trabalho como vão mostrar os seus objetos, a temática que lhe está associada e os produtos digitais que produziram. Alguns grupos decidem apresentá-lo do ponto de vista a) da significância histórica, a relevância do objeto e as relações que se pode estabelecer com o contexto histórico; b) outros desde a comparação, comparando o objeto antigo com os seus equivalentes atuais; c) outros desde as mudanças e as continuidades, mostrando a evolução do objeto e construção de linhas de tempo, etc.

Em relação à significância histórica: "Apreciei o valor dos objetos antigos e ver a potencialidade na sala de aula para trabalhar o currículo de forma internível e transdiciplinar" (A5) "Não sabia que o objeto escolhido tinha tanta história e era tão importante para a família”. (A6)

No 5. ${ }^{\circ}$ momento, é a montagem da exposição, e neste caso, a diferença do modelo, e não a elaboração da ficha de caracterização do objeto, que já se fez na $3 .^{\circ}$ etapa, mas sim a criação do ámbito expositivo, com os cartazes, materiais complementares, organização museográfica e a cenografia dos objetos, e os códigos QR, que estavam integrados na cenografia ou nos cartazes expositivos. Também, nos cursos dos anos letivos 2013-2014 e 2015-2016, escreveu-se 
o título da exposição no chão com giz, enquanto que, no curso de 2014-2015 se utilizou fita isolante e escreveu-se na parede de mármore. "Fazê-lo em formato vídeo e com uma exposição museística é mais lúdico e menos pesado, embora mais trabalhoso e elaborado". (A3) "A realização dos vídeos foi complicada, mas o ter que montar uma exposição e ver como cada grupo tinha criado o seu espaço de aprendizagem gostei muito, passamos bons momentos com os colegas e aprendemos muito" (A7) - Imagem 3.

Imagem 3. Composição com imagens de alguns espaços expositivos e os grupos de trabalho (curso 2015 -2016).

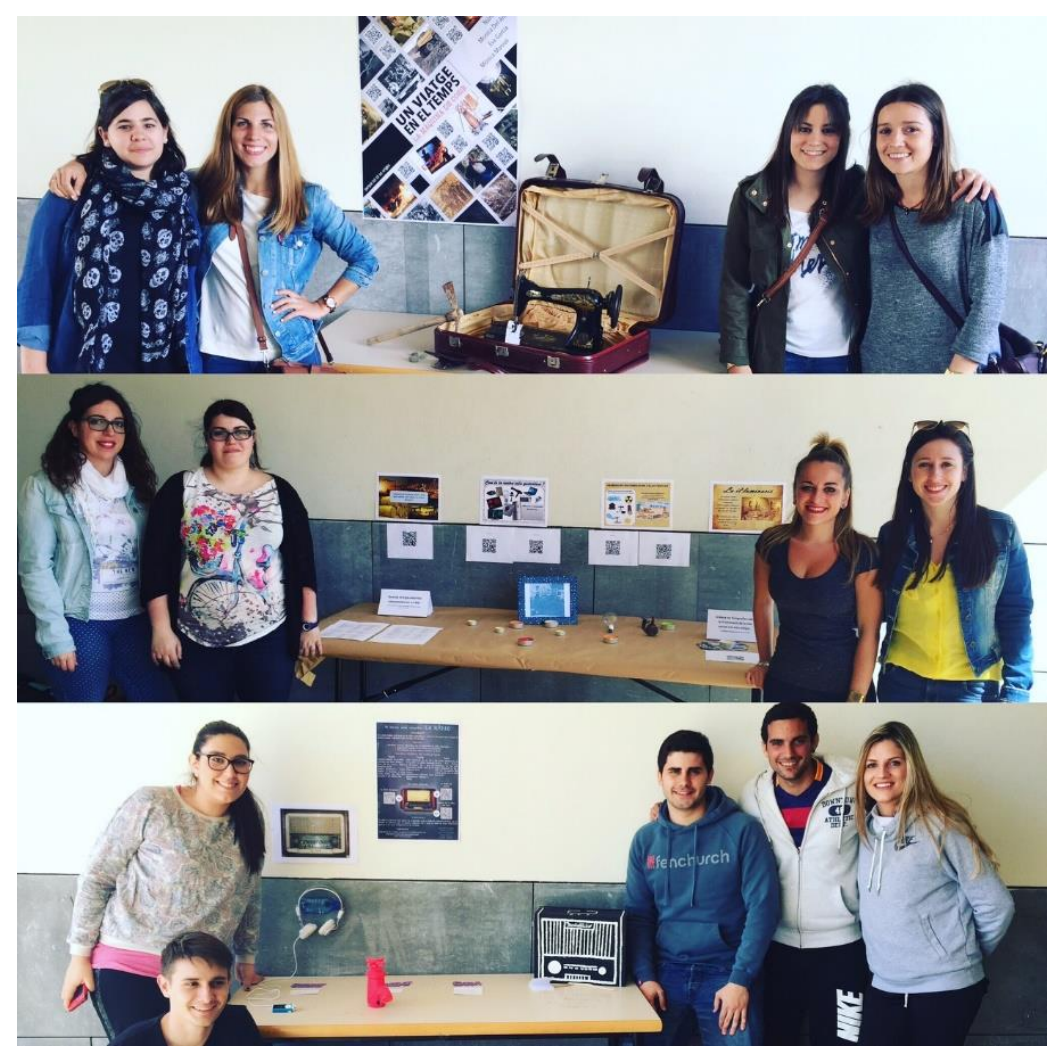

Fonte: autoras.

No $6 .^{\circ}$ momento é a inauguração, que se realizou no imediato após a sua montagem. Convidou-se colegas de outros anos e cursos, assim como professores, familiares e amigos. Os vários visitantes, incluídos os próprios colegas, visitavam os diferentes âmbitos temáticos da exposição, observavam as montagens expositivas, tiravam dúvidas com os seus autores e descarregavam os recursos digitais (através de leitores de código QR, como "BIDI") em formato audiovisual, na maioria dos casos, interagiam ente eles, colocando questões, fazendo comentários e reflexões.

Sobre a exposição, o trabalho com códigos QR e o partilhar de experiências: "Trabalhar a história a partir das fontes e dos códigos QR dos colegas foi bastante diferente em relação ao modo como trabalhava até agora." (A6) "Depois de ter vivenciado partilhei-o com outros 
conhecidos fora da universidade, e espero poder fazê-lo também na aula, já que graças a este trabalho temos vivido experiências únicas". (A8) - Imagem 4.

Imagem 4. Detalhe da exposição com códigos QR (curso 2015-2016).

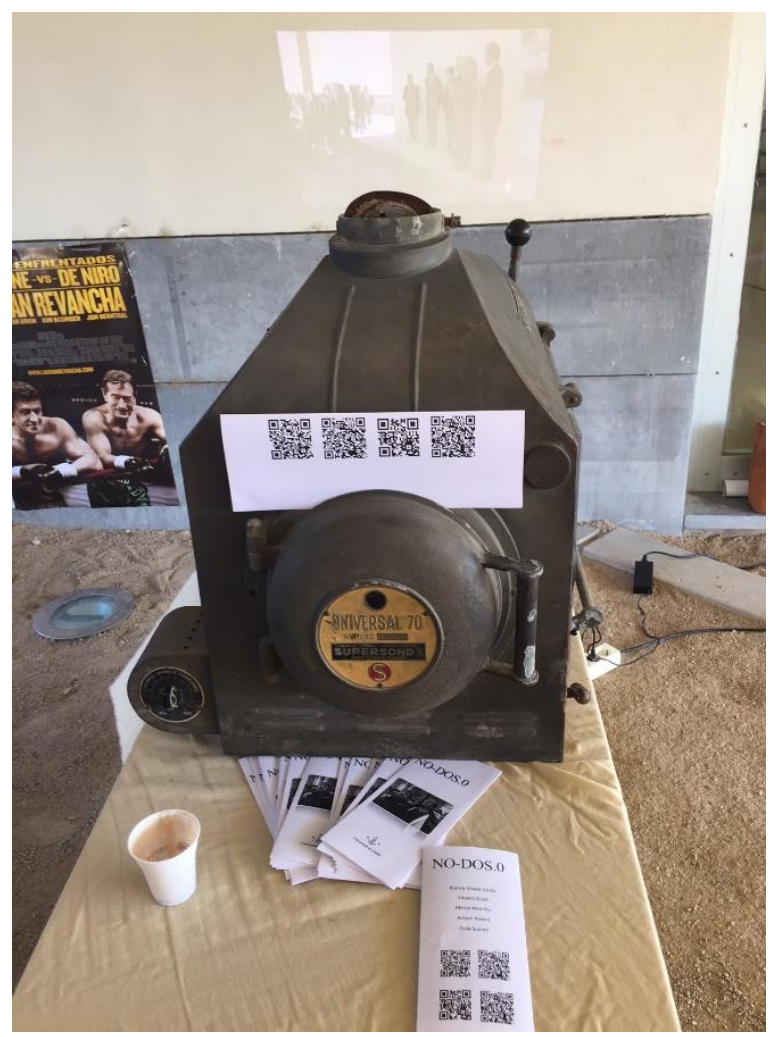

Fonte: autoras.

Estudo de caso 2- A construção do museu na sala de aula com objetos da família: um projeto com alunos do $2 .^{\circ}$ ano de primária

\section{Metodologia}

Esta experiência de investigação foi realizada numa turma do $2 .^{\circ}$ ano (24 alunos) de uma escola urbana de Braga (Portugal), turma que a investigadora acompanhava desde $01 .^{\circ}$ ano de escolaridade no âmbito do projeto de doutoramento (SOLÉ, 2009). Para a sua concretização seguiu-se a técnica do fio da história Storyline ou Storypath (MCGUIRE, 1997) e foi implementado ao longo de quatro sessões, correspondendo a duas etapas do projeto: a $1 .^{\text {a }}$ etapa-preparação da atividade (1. ${ }^{a}$ sessão); a $2{ }^{a}{ }^{a}$ etapa- construção do museu segundo a técnica do fio da história constituída por 7 momentos realizados ao longo de 3 sessões em que se 
aplicou o MCMSA. A metodologia de investigação utilizada foi inspirada na Grounded Theory (CORBIN; STRAUSS, 2008), sendo um estudo eminentemente qualitativo.

\section{Objetivos e questões de investigação}

Com este projeto procuramos: a) averiguar as potencialidades pedagógicas da construção de um museu de sala de aula para o desenvolvimento da compreensão histórica e temporal dos alunos do $2 .^{\circ}$ ano (7-8 anos) partindo da selecção, manuseamento e exploração de objetos trazidos de casa ou facultados por familiares, para a partir destes construirem o "Museu de sala de aula"; b) demonstrar como a exploração de objetos familiares (do museu) contribui para a iniciação dos alunos no processo de construção do conhecimeno histórico.

Partiu-se assim de duas questões: "Quais são as potencialidades pedagógicas do museu de sala de aula para a promoção da compreensão histórica e temporal das crianças de 7-8 anos?"; "De que modo a exploração de objetos familiares contribui para a construção do conhecimento histórico destes alunos?".

Técnicas e instrumentos de recolha de dados

Para a recolha de dados procedeu-se a várias técnicas e usaram-se váriosinstrumentos de recolha: aulas aúdio e vídeo-gravadas; observação participante; trabalhos dos alunos e notas de campo, possibilitando a elaboração posterior de diários de aula, que foram o principal instrumento de recolha de dados. Os dados recolhidos foram analisados qualitativamente de forma indutiva e categorizados inspirados na Grounded Theory (CORBIN; STRAUSS, 2008).

\section{Procedimentos}

Na 1. ${ }^{a}$ etapa de preparação da atividade de construção do museu pediu-se aos alunos para trazerem de casa um artefacto que pertencesse à família para se realizar um pequeno museu na sala de aula. Através de questionário, preenchido com a ajuda dos encarregados de educação ou familiares, procuraram obter informação sobre o seu objeto e a sua história, aplicando os procedimentos do MAFOP.Teriam que procurar responder às seguintes questões: O que é? Quantos anos tem? A quem pertenceu? De onde veio? Que cuidados devemos que ter com este objeto? Para além da recolha desta informação foi-lhes sugerido que procurassem saber o mais possível sobre o seu(s) objecto(s). ${ }^{* * * *}$

Na 2. ${ }^{\text {a }}$ etapa-Construção do museu concretizada em sete momentos seguiu-se o MCMSA : $1^{\circ}$ momento- criação do contexto do museu (que tipo de museu vão construir e qual a sua

\footnotetext{
**** Todos os nomes de alunos são pseudónimos.
} 
finalidade); $2 .^{\circ}$ momento - criação do local do museu (escolha do espaço onde será constituído) ; 3. ${ }^{\circ}$ momento- criação das personagens do museu (definem os papéis e as funções que cada um terá no museu); $4 .^{\circ}$ momento construção do contexto (a quem se destina e os seus objetivos); $5 .^{\circ}$ momento preenchimento de ficha de caracterização do objecto e montagem da exposição; $6 .^{\circ}$ momento- inauguração do museu.

\section{Resultados}

No 1. ${ }^{\circ}$ momento procuramos saber que ideias prévias os alunos tinham sobre o que é um museu, a sua função e finalidade. Sobre a sua finalidade, destacam mostrar objetos antigos: "Vai servir para as pessoas verem os objectos que nós trouxemos, as coisas antigas"(Catarina), reconhecer mudanças: "Mostrar coisas que agora já não se usam" (José); identificar diferenças entre objetos do passado e do presente em relação ao material, à forma e a nível tecnológico, etc. Imagem 5.

Imagem 5. Alguns dos objetos de família trazidos pelos alunos.

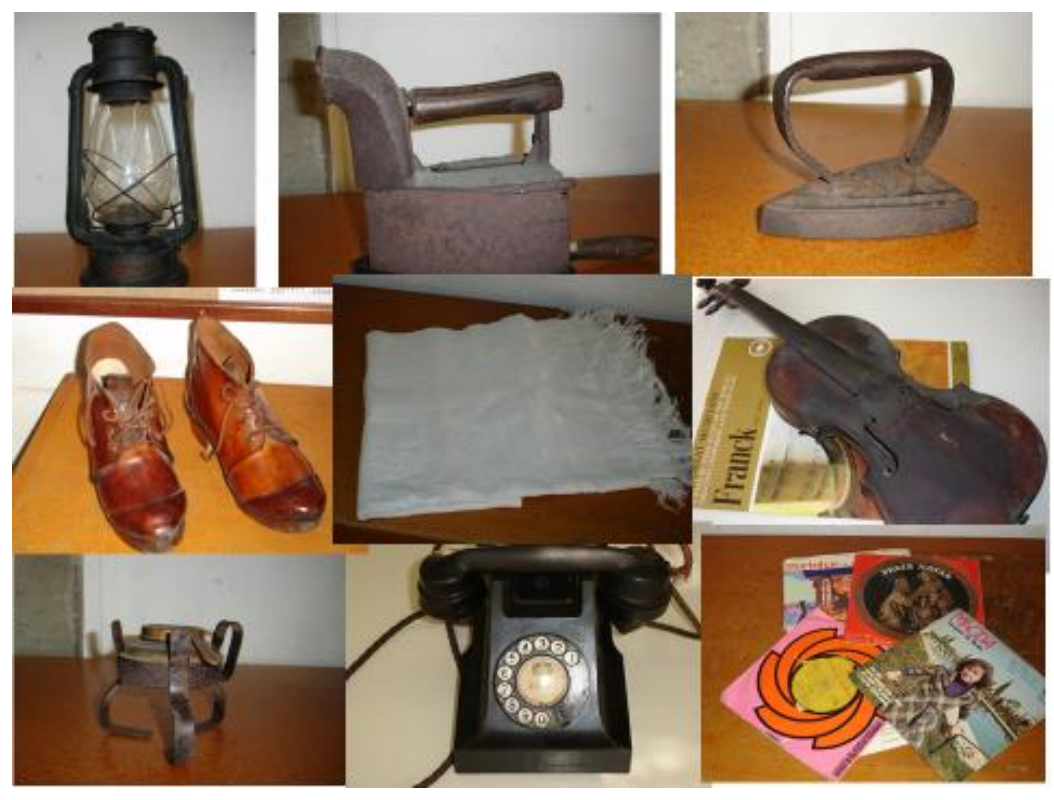

Fonte: autoras.

No 2..$^{\circ}$ momento discutiu-se o local e o tempo de duração da exposição do museu, quem o visitaria, afirmando que era para ser visitado por alunos e professores da escola e pelos seus encarregados de educação. 
Num 3. ${ }^{\circ}$ momento definiram os papéis e as funções que cada um teria no museu desde o director aos guias e monitores: "as guias são as que guiam e explicam os objetos" (Filipa); "os guardas são importantes para não deixarem roubarem as peças” (Maria).

No $4 .^{\circ}$ momento que correspondeu à construção do contexto, os alunos definiram a designação do museu, as finalidades do museu da família, a quem se destina e os seus objetivos. Escolheram designá-lo "O Museu dos objectos antigos das famílias dos alunos da turma". Em relação às finalidades propostas pelos alunos indicam: a) cronologia - "Mostrar os objetos antigos da nossa familia" (Alberto); b) significância histórica- "Para ver como são valiosos para nós; Para que é que serviam" (Maria); c) explicação histórica- "Explicar a função de cada um dos objetos no passado" (Duarte); d) comparação- "Comparar objetos antigos com objetos atuais que têm a mesma função" (Duarte); e) mudança e evolução- "Mostrar objectos com idade diferente" (Duarte). Os alunos reconheceram que nem todos os objetos têm a mesma idade (são da mesma época), e este museu permitiu mostrar vários objetos, alguns com a mesma função, mas com idades diferentes o que lhes possibilitou destacar mudanças e a evolução dos objetos com base no progresso tecnológico, ou até com base na moda da época.

No 5..$^{\circ}$ momento os alunos constroem a exposição, para isso, cada aluno escreve uma ficha de caracterização do seu objeto com base na informação recolhida. Nesta ficha de caracterização os alunos tinham que observar muito bem o objeto, identificar o que é (identificação); descrevê-lo, indicar a sua função (descrição e função); a idade (data); de onde veio (origem) e o seu proprietário, aplicando as etapas 1 a 4 do MAFOP. - Imagem 6.

Pudemos constatar que os alunos para preencher a ficha de caracterização do seu objeto procuravam sinais, pistas e indícios nos objetos que lhes permitisse explicar a sua função, como funcionava, de que era feito, a sua idade, a sua origem, confrontando as evidências observadas com informação recolhida, procedendo deste modo à construção do conhecimento histórico, bem evidente no extracto do diário de aula:

Alguns alunos observaram com mais atenção os seus objectos e encontraram informações que ainda não tinham reparado. Por exemplo o Silvério descobriu que o seu candeeiro tinha vindo de França e era de 1860. A Rita procurou no seu disco a informação de onde tinha vindo, e descobriu que este veio de Londres, Inglaterra e era de 1958. O Paulo leu na libra a data que lá constava, 1864. Na ficha preenchida em casa tinha a informação que a libra tem mais de 70 anos. $O$ mesmo aconteceu com o Guilherme, que identificou que a moeda de um escudo é de 1968. O Tinoco leu na parte debaixo do seu candeeiro a informação que lá constava que dizia, fabricado em Portugal. (Diário de aula-24-04-06) 


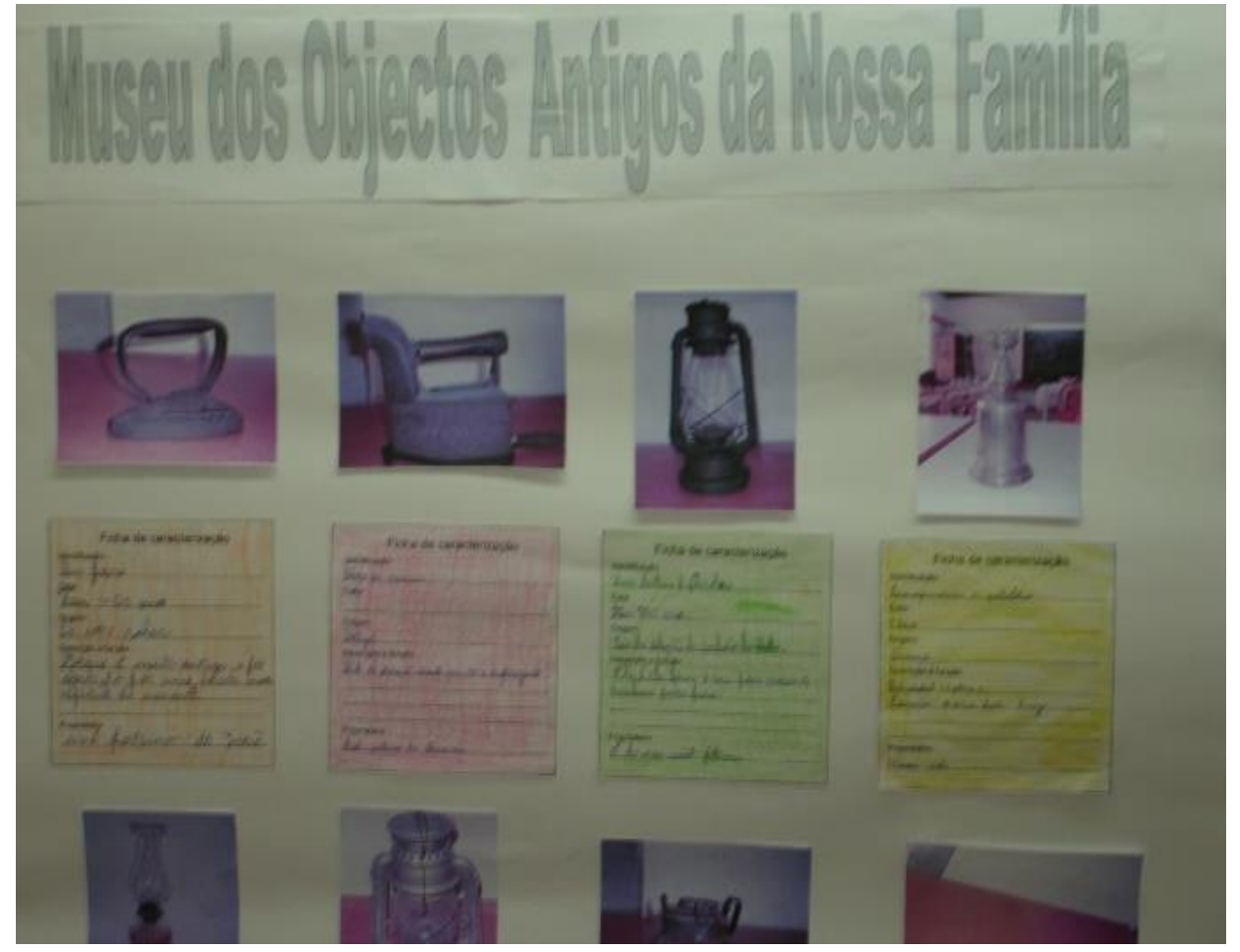

Fonte: autoras.

Em grande grupo, em momento de discussão cada aluno apresentou o seu objeto, tendo se promovido e desenvolvido várias competências históricas:

a) comunicação ao nível das descrição dos seus objetos- Este "ferro de passar em ferro, é muito pesado e enferrujado" (Filipa);

b) cronologia, ao datarem os seus objetos e compararem datações reconhecem que uns são mais antigos do que outros e alguns são da mesma época: "este ferro é mais velho do que o da Filipa" (comprovaram esta dedução quando o José informou os colegas que este ferro tem mais de 200 anos e que tinha vindo de um solar); evidência e causalidade- ao pegar no ferro antigo a aluna constata o peso deste e comenta "não devia ser muito prático passar a ferro devia dar cabo dos braços" (Filipa);

c) evidência e levantamanto de hipóteses sobre o funcionamento de alguns destes objetos. Por exemplo quando lhes perguntamos como funcionava o ferro antigo (a carvão) propuseram várias hipóteses mas à luz do presente (presentismo): "coloca-se água quente" (Tinoco) ou em relação ao ferro de passar com 200 anos que era aquecido em cima do fogão referiram: "era metido num fogão para aquecer" (Filipa); 
d) comparação em termos temporais, quando compararam objetos semelhantes, com a mesma função mas de épocas diferentes e com uma distância temporal significativa ou da mesma época, trabalharam os conceitos de contemporaneidade, continuidade e evolução, como o comprova o excerto do diário de aula:

Ouviram com muita atenção o Roberto que descreveu o seu candeeiro a petróleo: veio da estação de comboios do Porto, é de ferro e era para avisar os comboios para parar e tem cerca 150 anos e é do avô paterno que trabalhava nos comboios. O Silvério descreve assim o seu objeto: lamparina a petróleo, é de 1860, veio de França, é de metal, é de cobre, servia para dar luz, pertenceu ao meu pai. A Filipa também trouxe um candeeiro a petróleo: descrevendo-o: origem é de Portugal, base de vidro, cor amarela, parte superior em vidro transparente, muito antigo, função é iluminar, e é da minha avó paterna. [...] O Tinoco apresenta assim o seu objecto: é um candeeiro. Para a Catarina este candeeiro é mais velho do que o do Roberto. Os colegas parecem não concordar com ela, embora não soubessem a idade deste. Tem inscrito a sua origem, fabricado em Portugal. Pedi para ouvirem o que o Tinoco tinha a dizer acerca dele: é um candeeiro a petróleo, tem 50 anos. (D. A. 2. ${ }^{\circ}$ ano 24-04-06)

e) comparação e relação de objetos, como o de associar a roca às toalhas de linho que vários alunos trouxeram, reconhecendo que estas, pelos bordados deveriam ser da mesma época (contemporâneas), informação confirmada pelos dados recolhidos pelos alunos.

f) mudança ao compararem por exemplo os atuais CDs com os discos de vinil, reconheceram mudanças a nível tecnológico.

g) cronologia em termos de datação constatou-se que embora os alunos não sejam ainda capazes de datar os objetos quando não tem essa informação, são capazes no entanto de reconhecer por comparação se determinada datação é ou não razoável, apresentando argumentos para refutar hipóteses de datação pouco prováveis.

h) inferências e deduções, como por exemplo quando observam as socas que a Alexandra trouxe comentam: "Não devem ser confortáveis, devem ser duras" (Filipa); ou mesmo sobre o seu tamanho: "Parecem de anões" (Roberto). A Alexandra explicou que este objeto que trouxe: "têm pelo menos 40 anos, foram compradas na feira, fabricadas em Portugal e eram usadas no campo, a sola é de madeira e a parte superior é de couro". Vários alunos associaram este tipo de calçado ao usado ainda hoje nos ranchos, o que permitiu constatar a continuidade da sua utilização embora em contextos diferentes. 
Esta diversidade de objetos trazidos pelos alunos contribuiu para promover o sentido de tempo histórico, aumentado pela discussão dos alunos sobre as mudanças tecnológicas representadas pelos objetos.

Para a organização da exposição os alunos sugeriram que estes deveriam ser agrupados por secções e colocadas dentro de cada seç̧ão por ordem temporal do mais antigo para o mais recente: todos os candeeiros e lamparinas juntos (Roberto), todos os discos de vinil (Alberto), os ferros de passar (Maria), as toalhas, junto da toalha a roca, o guarda-jóias, as jóias, o portamoedas, a moeda e o cofre, as socas propuseram que ficasse junto da roca, por ser do campo, o violino e o livro junto dos discos por estar ligado à cultura e também o telefone e a moca (instrumento de música).

Realizaram em conjunto os convites de dois tipos, um para os alunos e professores da escola e outro para os encarregados de educação e escreveram o discurso de abertura, tarefas realizadas com grande entusiasmo e motivação, contribuindo ca da um de forma colaborativa para o projeto do museu.

Numa outra sessão ordenaram do mais antigo para o mais recente cinco objetos (telefone, ferro de passar, um disco em vinil, o candeeiro a petróleo dos comboios e a moeda de um escudo). Foram unânimes em colocarem como mais antigo o ferro de passar apresentando várias justificações, umas com base na evidência material, outros com base no seu modo de funcionamento ou ainda no conhecimento da sua datação: "Tem muita ferrugem e os ferros grandes inventaram-se mais tarde" (Guilherme); “Aquece-se numa pedra” (Hélder); "O Pedro disse que ele tinha 200 anos" (Mariana). Em segundo lugar, como mais antigo colocaram o candeeiro a petróleo do caminho-de-ferro justificando: "Porque o Roberto disse que tinha 150 anos. Servia para parar os comboios" (Alberto). Colocam em seguida em terceiro lugar a moeda de 1968 justificando pelo conhecimento da idade de cada um dos objetos: "o Guilherme disse que a moeda dele tem 38 anos e este (telefone) tem 30 anos" (Mariana). Em quinto lugar como mais recente disseram ser o disco de vinil que tinha 20 anos. Nesta sessão elaboraram cartazes com as fotografias dos objetos e sua caracterização e entregaram pelas salas os convites aos colegas de outras turmas para visitarem o museu na sua sala de aula. - Imagem 7. 
Imagem 7. Objetos da família catalogados.

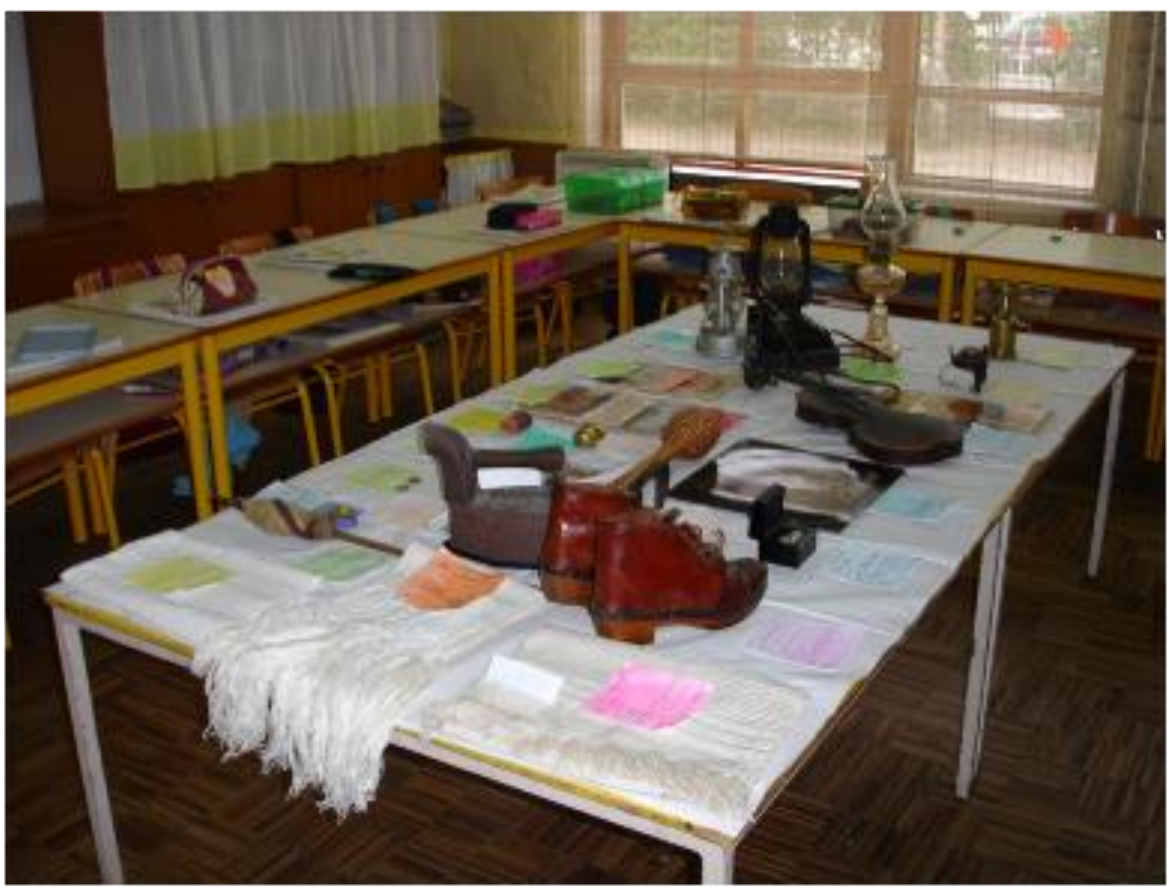

Fonte: autoras.

6. ${ }^{\circ}$ momento- Inauguração do museu. O museu da turma foi visitado por todas as turmas da escola e por quase todos os encarregados de educação e vários familiares, que ficaram maravilhados com o resultado desta atividade. As guias exerceram a sua função, mostravam os objetos, colavam-lhes questões: Qual é o objeto mais antigo? Perguntou-lhes a Marta. Um dos alunos aponta para o ferro e refere: é aquele porque tem 200 anos, tendo lido parte da informação contida na ficha de caracterização. Também nenhum dos alunos que vi sitaram o museu soube explicar como funcionava o ferro de passar a carvão. Uma das guias mostroulhes o interior do ferro, explicou que este tinha uma espécie de esqueleto e que aqui se colocava o carvão em brasa. Alguns dos objetos intrigaram-nos e colocaram várias questões: Para que servia? Como era usado? De que eram feitos? etc., (eixo 2, 3 e 4 do MAFOP) e eram as guias ou os próprios alunos que tinham trazido o objeto que respondiam. Alunos de outras turmas reconheceram alguns dos objectos por os terem visto em casas dos avós ou familiares. - Imagem 8. 
Imagem 8. Montagem do museu na sala de aula.

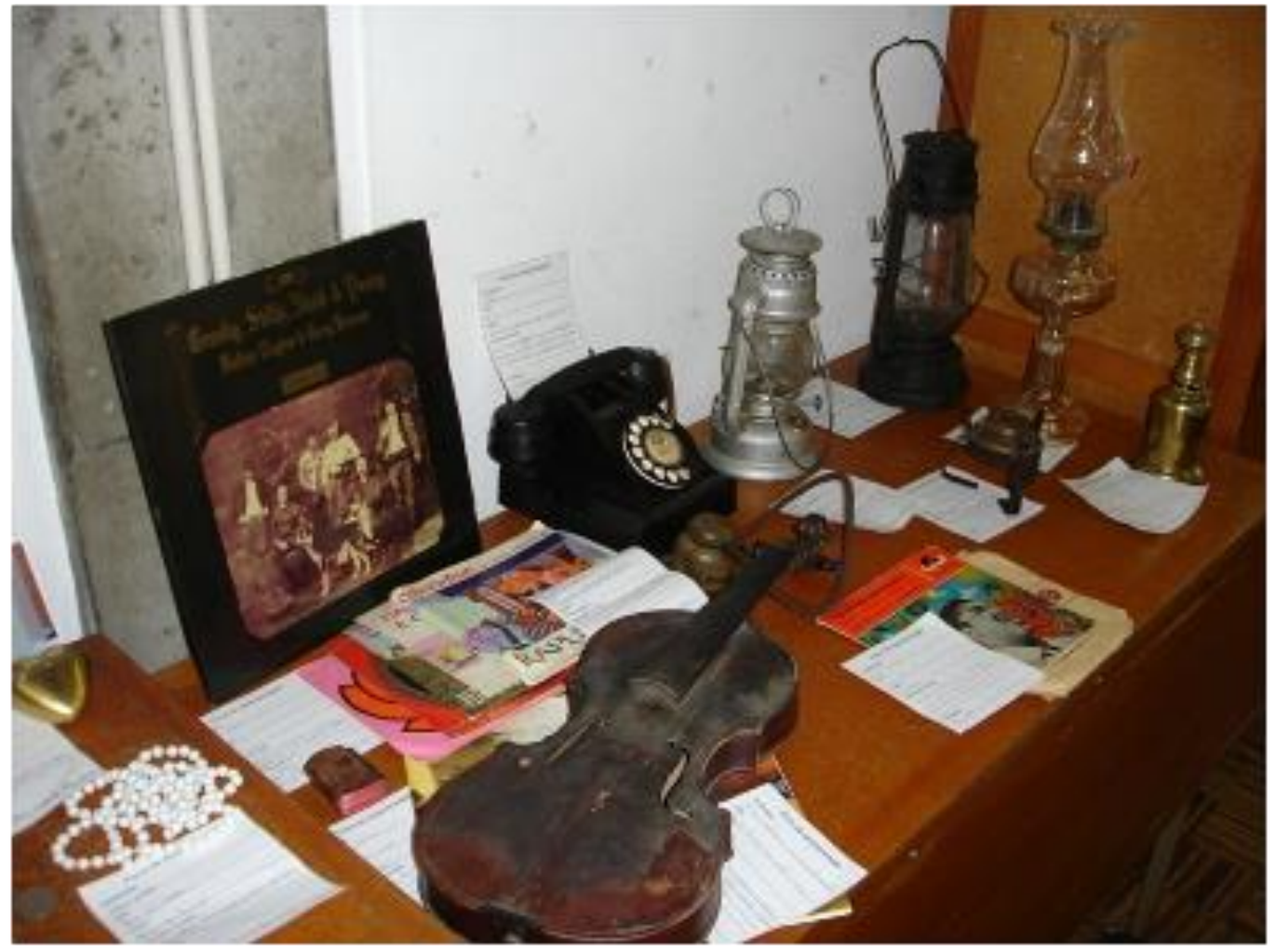

Fonte: autoras.

\section{Conclusões}

Como se compreende não se pretendeu com estes dois estudos de caso estabelecer generalizações, mas destacar as potencialidades da didática do objeto em dois contextos de aprendizagem diferentes, um com futuros professores de ensino primário na sua formação inicial e no outro contexto com alunos de primária, procurando-se demonstrar a relevância do modelo isomórfico, em que se procura que os futuros professores realizem, em contexto de aprendizagem e formação, práticas que as possam implementar no futuro com os seus alunos.

O modelo isomófico também é aplicável ou transferido do modelo de contexto da educação formal à não formal, visto pensarmos que os modelos aplicados podem também implementar-se em museus e outros espaços patrimoniais com o objetivo de permitir à comunidade, cada vez mais diversa, das nossas sociedades, a prender a partir dos objetos da 
família próximos ou mais afastados, compreender o "outro" através das histórias que narram estes objetos e criar deste modo espaços de entendimento e de diálogo na sociedade.

Em relação ao estudo de caso 1 podemos apresentar algumas conclusões vinculadas ao trabalho de didática do objeto e análise de fontes objetuais e a realização de uma exposição museística centrada nos objetos e com recursos didáticos diversos descarregados através de sistemas de telemóvel. Algumas das contribuições do projeto são as seguintes:

1. mostrar aos futuros professores e professoras o potencial didático dos objetos como fontes do passado: "Dei-me conta que trabalhando a partir de um objeto próximo, ficas cativo dele e dá-te vontade de aprender e saber mais, e isso faz com que o trabalho não seja só para entregar ao professor que o pede, mas também para minha satisfação". (Aluno 8). "A partir dos objetos os alunos podem chegar a respeitar os objetos e saber que todos têm algum coisa para contar". (A3)

2. aproximar o aluno das fontes do património local e familiar: "Uma coisa importante é que se trata de um objeto que tenho em casa e que nunca lhe prestei atenção até agora, e que tive que o analisar". (A9) "Escolher um objeto próximo, permitiu envolver familiares e pessoas chegadas". (A11)

3. tomar cosnciência do meio social e cultural através dos seus vestígios ou fontes, sobretudo as objetuais e orais: "Este trabalho serviu-me para abrir a mente elevarme a questionar sobre o meio que me rodeia" (A12) "Agradou-me muito poder contar com as explicações dos meus avós" (A11).

4. apresentar uma didática da história através de metodologias por descoberta: "O facto de trabalhar de maneira indutiva levou os alunos a entender e ter uma melhor perceção da realidade e valorizar ativamente a sua conceção da sociedade e do mundo em que vive". (A11) "Quero aplicá-lo com os meus alunos para que aprendam a partir da investigação". (A13)

5. mostrar metodologias e ferramentas de classificação de fontes: "Abriram-se-me novas vias de comunicação intressantes para trabalhar tanto na escola como a nível pessoal". (A12)

6. fomentar experiências de trabalho e de aprendizagem cooperativo: "Gostei muito porque aprendi muito com os outros". (A15)

7. fomentar competências de pesquisa de informação e de seleção crítica da informação recolhida: "Gostei muito documentando-me". (A14) "Extraí informações de fontes do passado! Fontes diretas! Fontes primárias.”(A16) 
8. fornecer ferramentas para a construção de recursos didáticos digitais com recurso ao telemóvel, com uso digital de código QR: "Achei um maneira original de mostrar o que tinhamos aprendido, não tem que ser sempre apresentações em PowerPoint ou trabalhos escritos. E aprendi o potencial dos códigos QR. De certeza que os utilizarei novamente" (A15)

9. trabalhar a inter e transdisciplinariedade: "Penso que todos os conhecimentos que aprendemos em história podem-se aplicar quando ensinamos algum conceito e enriqueci a minha interdisciplinariedade". (A17)

Por último, cabe mencionar que são muitas as vozes que comentam que a sua aprendizagem foi significativa. Neste sentido o aluno 16 comenta "Acho que será difícil esquecer o que aprendi fazendo este trabalho" e o aluno 19 diz que "Foi uma maneira diferente de aprender, uma maneira que nos marcou muito e por esse motivo foi proveitoso e necessário". Também salientam como aspeto positivo ter sido uma experiência agradável, o que lhes permitiu ver de outra forma a história e a sua didática. "Não é tanto o que aprendi mas o prazer com que o fiz". (A20)

O estudo de caso 2, centrou-se na exploração de objetos familiares que os alunos trouxeram de sua casa e na construção de um museu em sala de aula. Este projeto permitiu evidenciar o pensamento histórico das crianças com recurso aos objetos antigos como evidência histórica. Assim podemos enunciar um conjunto de contributos que este projeto proporcionou:

1. reforçar o espírito de comunidade, de responsabilidade e colaboração entre os alunos e entre estes e a sua família e encarregados de educação;

2. motivar os alunos a estudar o passado e a história através de objetos da vida quotidiana dos seus familiares;

3. desenvolver capacidades de observação, descrição, linguagem oral e escrita (manuscrita e em computador), manipulação, datação e sequencialização;

4. demonstrar que o recurso a objetos facilita aos alunos a elaboração de inferências e deduções sobre a sua funcionalidade e a época em que foram utilizados;

5. mostrar que alguns alunos procuram ainda explicar o modo de funcionamento de alguns objetos no passado com base em objetos do presente com a mesma função (presentismo);

6. fomentar nos alunos o saber questionar, elaborar hipóteses, procurar informações, realizar conjeturas e iniciá-los na crítica às fontes; 
7. promover a emergência da imaginação histórica e do pensamento histórico;

8. proporcionar o desenvolvimento da compreensão do tempo histórico através de exercícios de datação, comparação, reconhecendo mudança, continuidade e progresso;

9. trabalhar a cronologia, através da datação dos objetos, da sua sequencializaçã o, assim como pela associação do ano à década e ao século;

10. fomentar a utilização de vocabulário de tempo qualitativo: "são da mesma época"; "é mais antigo"; "é mais novo";

11. introduzir novo vocabulário, conceitos e conhecimentos.

Como conlusão geral podemos afirmar que a construção de um museu de sala de aula permite desenvolver nas crianças um conjunto de competências históricas mas também transdisciplinares. Comprovámos que, tal como Singer e Singer (2004a) e Schmidt e Garcia (2007) defendem, este tipo de estratégia, pela procura de objetos relevantes da família, promove o sentido de comunidade na sala de aula. A articulação entre escola-família sai reforçada, pelo envolvimento dos pais e encarregados de educação, por proporcionarem momentos de pesquisa e inter-acção com os seus educandos, na seleção e recolha de informação acerca dos objetos antigos para o museu. Reforça-se também a responsabilização dos alunos na construção do conhecimento histórico, através da aprendizagem cooperativa que este tipo de projeto propicia.

O envolvimento dos alunos transparece pela sua motivação em aprender sobre o passado, procurando imaginar como estes objetos seriam usados no passado, comparando-os com objetos similares no presente.

Conclui-se a partir deste projeto que a construção de um museu em sala de aula revela-se uma importante estratégia para envolver as crianças na seleção, organização e comunicação de informação histórica, contribuindo para desenvolver um conjunto de competências históricas para além de outras de caracter transversal: compreensão temporal (mudança e cronologia: datação e sequencialização), interpretação de fontes, compreensão histórica contextualizada; literacia oral e escrita e utilização das TIC.

Por isso, a construção de um museu de sala de aula e a utilização de objetos é um ótimo meio de introduzir as crianças em contacto com vestígios do passado e nos métodos da construção da história. Fomenta nos alunos o questionar, o elaborar hipóteses, procurar informações, realizar conjeturas e iniciá-los na crítica às fontes. A construção de museus na sala de aula constituem formas importantes de introduzir a história a crianças pequenas, possibilita-lhes descrever e contrastar a vida na atualidade e no passado, enumerar diversas características do passado e compreender as mudanças ao longo do tempo, proporcionando o 
desenvolvimento da compreensão e do pensamento histórico e de competências essenciais para melhor compreender o passado e melhor orientar-se no presente.

\section{Referências}

AGUIAR, Liliana. Ver, tocar e sentir a Maia: um projeto de Mediação Patrimonial no Museu de História e Etnologia da Terra da Maia. 2015. Dissertação (Mestrado em Museologia) Faculdade de Letras da Universidade do Porto, Porto, 2015.

EGEA, Alejandro; ARIAS, Laura. La arqueología llega a las aulas. Objetos y otras fuentes primarias para la enseñanza de la historia. In: SOLÉ, Glória (ORg.). Educação Patrimonial: contributos para a construção de uma consciência histórica. Braga: Centro de Investigação em Educação (CIEd), 2015. p. 151-169.

BARNSDALE-PADDOK, Linda; HARNETT, Penelope. Promoting play in the classroom; children as curators in a classroom museum. Primary History, London, v. 30, p. 19-21, 2002.

BONASTRA, Quim; JOVÉ, Glòria; LLONCH, Nayra. (Inter)(Trans)disciplinariedad en formación de maestros. Aula de Innovación Educativa, Barcelona, v. 239, p. 16-22, 2015.

CAINELLI, Marlene. Educação Histórica: perspectivas de aprendizagem da história no ensino fundamental. Educar em revista, Curitiba, n. esp., p. 57-72, 2006.

COOPER, Hilary. History in the Early Years: Teaching and Learning in the first three Years of School. London: Routledge, 1995.

COOPER, Hilary. The Teaching of History in Primary Schools- Implementation the Revised National Curriculum. 3. ed. London: David Fulton, 2005.

CORBIN, Juliet; STRAUSS, Anselm. Basics of qualitative research. Techniques and procedures for Developing Grounded Theory. Thousand Oaks, CA: Sage, 2008.

DURBIN, Gail; MORRIS, Susan; WILKINSON, Sue. A Teacher's Guide to Learning from Objects. London: English Heritage, 1996.

FERNANDES, Carmen.A explicação histórica com base nos artefactos: um estudo com alunos do $3^{\circ}$ ciclo do ensino básico. 2009. Dissertação (Mestrado em Educação) - Universidade do Minho, 2009. 
HARNETT, Penelope. Shared Heritages? Investigating Ways of life in the Past to promote European Consciousness with Children in Primary schools. In ROSS, Alistair (Ed.) Citizenship Education: Europe and the World. London: CiCe, 2006, pp.169-174.

HAWKES, Angela. Objects or Pictures in the Infant Classroom? Teaching History, v. 85, p. 3035, 1996.

HISTORICAL ASSOCIATION'S OCCASIONAL PAPER. School Museums and Primary History. London, 1994.

HOODLESS, Pat. Time and Timelines in the Primary School. London: Historical Association, 1996.

JOVÉ, Glòria. Viatges escolars a través del temps a partir d'un quadern de rotació del mestre Pau Farrús. Mascançà. Revista d'estudis del Pla d'Urgell, anuari, v. 6, p. 45-60, 2015.

KERRIGAN, Sonia.Creating a community school museum: theory into practice. Internacional Journal of Historical Learning, Teaching and Research, New York, v. 2, n. 1, p. 1-7, 2001.

LLONCH, Nayra. El método por descubrimiento en la enseñanza de ciencias sociales: ejemplificación y análisis. In: ÁVILA, R. M.; RIVER, P.; DOMÍNGUEZ, P. (Ed.). Metodología de investigación en Didáctica de las Ciencias Sociales. Zaragoza: Institución Fernando el Católico, 2010. p. 597-606.

LLONCH, Nayra; MARTÍN, Carolina. Los códigos QR y su potencial como herramientas de educación patrimonial interdisciplinar en las aulas. In: GUZMÁN, María (Ed.). Patrimonio y educación. una propuesta integradora. Granada: Universidad de Granada, Junta de Andalucía, 2016. p. 167-177.

MARGERY, Enrique. Complejidad, transdisciplinariedad y competencias. Cinco viñetas pedagógicas. Costa Rica: Uruk Editores, 2010.

MCGUIRE, Margit. Storypath Foundations: An Innovative Approach to Teaching Social Studies. Chicago, IL: Everyday Learning Corporation, 1997.

NICOLESCU, Basarab. La transdisciplinariedad Manifiesto. México: Multidiversidad Mundo Real Edgar Morín, 2009.

NULTY, Patricia. Talking about artefacts at Key Stage 1. In: HOODLESS, Pat (Ed.). History and English in Primary School: Exploting the Links, London: Routledge, 1998. p. 20-34.

PINTO, Maria Helena. Educação histórica e patrimonial: conceções de alunos e professores sobre o passado em espaços do presente. 2011. Tese (Doutorado em Educação) - Universidade do Minho, Braga, 2011. 
REPÚBLICA PORTUGUESA. Ministério de Educação. Metas de aprendizagem. 2010. Disponível em: < <http://metasdeaprendizagem.dge.mec.pt/metasdeaprendizagem.dge.mec.pt/ index.html $>$. Acesso em: 17 set 2016.

RIBEIRO, Flavio. O pensamento arqueológico na sala de aula de História. 2002. Dissertação (Mestrado em Educação) - Universidade do Minho, Braga, 2002.

SABATÉ, Miquel; GORT, Roser. Museos y comunidad. Un museo para todos los públicos. Gijón: Ediciones Trea, 2012.

SANTACANA, Joan; LLONCH, Nayra. Manual de didáctica del objeto en el museo. Gijón: Ediciones Trea, 2012.

SINGER, Judith; SINGER, Alan. Creating a museum of family artifacts. Social Studies and the Young Learner, v. 17, n. 1, p. 5-10, 2004a.

SINGER, Judith; SINGER, Alan. Building a family history file: a family artifact museums project. Social Studies and the Young Learner, v. 17, n. 1, p. 17-18, 2004b.

SCHMIDT, Maria Auxiliadora; GARCIA, Tania Braga. O trabalho com objetos e as possibilidades de superação do sequestro da cognição histórica: estudo de caso com crianças nas séries iniciais. In: SCHMIDT, Maria Auxiliadora; GARCIA, Tania Braga (Eds.). Perspectivas de Investigação em Educação Histórica. Curitiba: UFPR, 2007. v. 1, p. 52-57.

SOLÉ, Glória. A História no $10^{\circ}$ Ciclo do ensino básico: a concepção do tempo e a compreensão histórica das crianças e os contextos para o seu desenvolvimento. 2009. Tese (Doutorado em Educação) - Universidade do Minho, Braga, 2009.

SOLÉ, Glória. A museum in the classroom: learning History from objects. Primary History, London, v. 61, p. 20-22, 2012a.

SOLÉ, Glória. O museu de sala de aula: aprender história com os objectos. In SCHMIDT, Maria Auxiliadora (Ed.). Atas do XII Congresso Internacional Jornadas de Educação Histórica "Consciência Histórica e as novas tecnologias da informação e comunicação", Curitiba: LAPEDUH (CD/Rom), 2012b, pp. 315-332.

VAL DEL OMAR, José. Estampas. Documentary. 1932. Disponível em: <https://www.youtube.com/watch?v=4iti1MZOdeA>. Acesso em: 10 set. 2016.

VELLA, Yosanne. Extending Primary Children's Thinking of the use of artefacts. Internacional Journal of Historical Learning, Teaching and Research, New York, v. 1, n. 2, p. 1-11, 2001.

Recebido em 23.10.2016 - Aprovado em 30.11.2016 